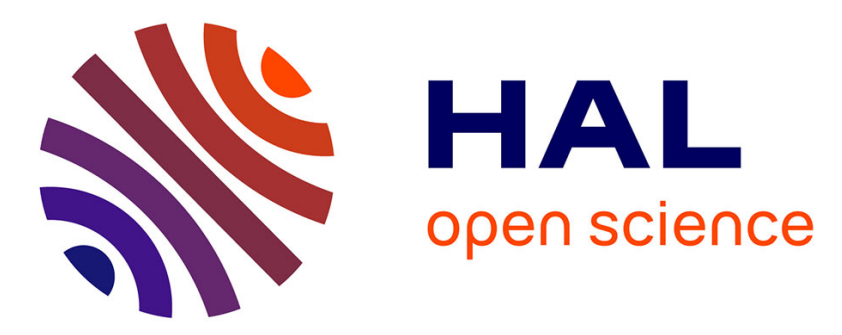

\title{
Crystallization Mechanisms and Rates of Cyclopentane Hydrates Formation in Brine
}

Son Ho-Van, Baptiste Bouillot, Daniel Garcia, Jérome Douzet, Ana Cameirão, Saheb Maghsoodloo-Babakhani, Jean-Michel Herri

\section{To cite this version:}

Son Ho-Van, Baptiste Bouillot, Daniel Garcia, Jérome Douzet, Ana Cameirão, et al.. Crystallization Mechanisms and Rates of Cyclopentane Hydrates Formation in Brine. Chemical Engineering and Technology, 2019, 42 (7), pp.1481-1491. 10.1002/ceat.201800746 . hal-02103532

\section{HAL Id: hal-02103532 \\ https://hal.science/hal-02103532}

Submitted on 18 Apr 2019

HAL is a multi-disciplinary open access archive for the deposit and dissemination of scientific research documents, whether they are published or not. The documents may come from teaching and research institutions in France or abroad, or from public or private research centers.
L'archive ouverte pluridisciplinaire HAL, est destinée au dépôt et à la diffusion de documents scientifiques de niveau recherche, publiés ou non, émanant des établissements d'enseignement et de recherche français ou étrangers, des laboratoires publics ou privés. 


\title{
Crystallization mechanisms and rates of Cyclopentane Hydrates formation in Brine
}

\author{
Son Ho-Van ${ }^{1,2 *}$, Baptiste Bouillot ${ }^{1 *}$, Daniel Garcia ${ }^{3}$, Jérome Douzet ${ }^{1}$, Ana Cameirao ${ }^{1}$, \\ Saheb Maghsoodloo-Babakhani ${ }^{1}$, Jean-Michel Herri ${ }^{1}$ \\ ${ }^{I}$ Mines Saint-Etienne, Univ Lyon, CNRS, UMR 5307 LGF, Centre SPIN, F - 42023 Saint-Etienne \\ France; \\ ${ }^{2}$ Oil Refinery and Petrochemistry Department, Hanoi University of Mining and Geology, \\ Duc Thang, Bac Tu Liem, Hanoi, Viet Nam \\ ${ }^{3}$ Mines Saint-Etienne, Univ Lyon, Univ Jean Moulin, Univ Lumière, Univ Jean Monnet, ENTPE, \\ INSA Lyon, ENS Lyon, CNRS, UMR 5600 EVS, Centre SPIN, F - 42023 Saint-Etienne France \\ *Correspondence: Son Ho-Van (E-mail: son.ho-van@emse.fr) and Dr. Baptiste Bouillot (E-mail: \\ bouillot@emse.fr) Mines Saint-Etienne, Univ Lyon, CNRS, UMR 5307 LGF, Centre SPIN, F - \\ 42023 Saint-Etienne France;
}

\section{Published in : Wiley, Chemical Engineering Technology 2019, 42; DOI: 10.1002/ceat.201800746}

\begin{abstract}
Clathrate hydrates most often grow at the interface between liquid water and another fluid phase (hydrocarbon) acting as a provider for the hydrate guest molecules, and some transfer through this shell is required for the hydrate growth to proceed, thus self-limiting the reaction rate. An optical microscope and a horizontal reaction cell are utilized to capture the shell growth phenomenology and to estimate the hydrate layer growth rates from sequential pictures. Cyclopentane (CP) is chosen as the hydrate-forming molecule to obtain hydrates at low pressure. Experimental hydrate layer growth rates are provided for the $\mathrm{CP}+$ brine system, using various combinations of salts and various degrees of subcooling.
\end{abstract}

Keywords: Cyclopentane, Clathrate Hydrates; Crystallization; Brine; Mass transfer.

\section{Introduction}

Clathrate hydrates are ice-like and non-stoichiometric compounds consisting of water molecules 
forming polyhedral hydrogen-bonded cavities that enclose guest molecules such as $\mathrm{CO}_{2}, \mathrm{CH}_{4}$, $\mathrm{C}_{2} \mathrm{H} 6, \mathrm{C}_{3} \mathrm{H}_{8}$, or even Cyclopentane (CP) [1]. The clathrate hydrates usually form at high pressures and at low temperatures depending on the guest molecules. These compounds have been widely studied over decades to understand and prevent hydrate plugging in pipelines [2]. More recently, clathrate hydrates have gained increasing attention due to their many potential applications for example: gas transportation [3-5], gas storage [6-12], gas separation [13-15], refrigeration [16,17], or desalination [18-23].

In order to develop innovative clathrate hydrate-based techniques, and to better manage hydrate formation in multiphase flow, not only the formation conditions, phase equilibrium, are necessary, but also the crystallization mechanisms: nucleation, growth, agglomeration.

In former studies, our group focused on cyclopentane hydrates for water treatment/desalination application $[18,19]$. The formation temperature in brine have therefore been experimentally obtained and modelled. The present contribution focuses on cyclopentane hydrate formation mechanisms and rates using a small unstirred cell under microscope.

Cyclopentane hydrates $(\mathrm{CPH})$ form structure II clathrates at $7.1^{\circ} \mathrm{C}$ under atmospheric pressure. They are composed of 17 water molecules per cyclopentane molecule. Since cyclopentane is not miscible with water (solubility of $156 \mathrm{mg} / \mathrm{l}$ at $25^{\circ} \mathrm{C}$ [24]), the hydrate formers can be easily separated in a hydrate-based industrial application. Moreover, $\mathrm{CPH}$ formation from water + liquid cyclopentane (CP) may be viewed as a model analogue of gas hydrate crystallization in a water/oil emulsion under mild conditions. Therefore, it is an interesting system to study hydrate crystallization mechanisms, especially the mass transfer of the former species in the different phases, without the need of a pressurized experimental setup.

In the literature, many studies addressed mass transfer phenomena in clathrate hydrate formation [25-41]. In the most usual case, crystallization occurs at an interface between water, and another liquid phase, acting as a reservoir of the guest species. Therefore, a specific attention has been paid to mass transfer phenomena through this interface and the crystal layer that is formed. In quiescent systems, the crystalline layer prevents direct contact between water and guest molecules, and inhibits the hydrate formation (hydrate crust, or hydrate shell $[34,42,43]$ ). Hence, the mass transfer of water and/or guest molecules across the hydrate layer is a potential ratelimiting factor that controls the hydrate growth. Understanding the mass transfer through the hydrate layer is thus needed. 
It is worth mentioning here the early experimental studies that addressed the crystal growth rates and mas transfer rates through the hydrate layer [31,44-50], provide models [25,26,28,34,35,41,51], or perform molecular dynamics (MD) simulations [33,38]. The pioneering work of Mori and co-workers [25,26] explored theoretically the evolution of a hydrate layer thickness at the interface between water and another non-miscible phase of guest molecules. Their showed that a porous solid plate model is more realistic than the diffuse layer model due to the permeability of the hydrate film $[25,26]$.

Later, in 2010, Sun et al. [34] measured experimentally the hydrate film growth, and considered Mori's model as well as later developments (Peng et al.[52]). They concluded that the numerous factors that influence the hydrate layer growth rate in the model make the simulation very challenging. Abe et al. [45] also measured the hydrate film thickness growth for CO2 hydrates and suggested a model.

In the 2010s, Davies and co-worker have conducted valuable experimental studies. They used differential scanning calorimetry method to study the mass transfer phenomenon through methane hydrate layer at the interface in a non-mixing reactor [31]. They found that, at the beginning, hydrate layers at gas-water interface are porous, which facilitates the mass transfers. In addition, the mass transfer rate decreases with time, as the hydrate cavities are filled with guest molecules. Then, they utilized Raman spectroscopy to investigate the mass transfer mechanism across a methane hydrate film [30]. Their results indicate that water molecules are more moveable than gas molecules in the hydrate layer, and that the growth of gas hydrate is controlled by the water movement in the interior of the hydrate layer.

$\mathrm{Li}$ and co-workers $[47,48]$ reported the crystal growth of gas hydrates from methane and ethane by suspending a single gas bubble in water under different subcoolings. Their showed that, under low subcoolings, the growth of hydrate film is dominated by the film thickening, but not by lateral film growth. Importantly, simples kinetic models, as function of the subcoooling, could be used to correlate film growths

In another of their efforts, $\mathrm{Li}$ et al [32] also concluded that hydrate layer thickening at the interface is controlled by the outward transport of water across hydrate film, while the lateral growth is controlled by the mass transfer of the guest molecules $\left(\mathrm{CH}_{4}\right)$. Based this understanding, Kishimoto et al. [35] proposed a correlation of the lateral growth rate to mass transfer resistance. Very recently, Sun et al. [28,41,51] published a remarkable series of articles for modelling the 
mass transfer in the hydrate shell. While their system is not a liquid-liquid interface, they looked into details at the interface between gas bubbles and water, and of course the inside of the hydrate shell. All mass and heat transfer equations are written to represent the problem of the hydrate crystallization and growth at the interface between a gas bubble and water.

Finally, MD simulations have been performed to investigate molecular mobility of interstitial $\mathrm{H}_{2} \mathrm{O}$ molecules across hydrate cavities [33,38]. Liang et al [38] found that interstitial molecules diffusion could be a key mechanism for the mass transfer of $\mathrm{H}_{2} \mathrm{O}$ across the hydrate layer. Lo et al. [33] explored the water vacancy driven diffusion of guest molecule through hydrate layer, and estimated the guest $\left(\mathrm{CO}_{2}\right)$ diffusivity.

This short review highlights two important points: there are not so many experimental studies that provide a local insight of the hydrate growth at the interface and furnish interface growth rates, or mass diffusion rates. Secondly, the modelling of such system is challenging.

In the present contribution, a new experimental insight is explored. Unlike other studies, the experimental set-up is a non-agitated small system. Moreover, this system geometry presents a vertical interface between water and cyclopentane, allowing a top view of the lateral hydrate growth under a microscope. There are two objectives: to measure the $\mathrm{CPH}$ formation rate from a two-phase system (brine-cyclopentane), and to discuss the crystallization mechanism. Moreover, both the influence on the aqueous electrolyte (four saline solutions of $\left\{\mathrm{NaCl}, \mathrm{NaCl}-\mathrm{MgCl}_{2}\right.$, $\left.\left.\mathrm{NaCl}-\mathrm{KCl}-\mathrm{MgCl}_{2}, \mathrm{Na}_{2} \mathrm{SO}_{4}\right\}\right)$ and the influence of subcooling $\left(2.5^{\circ} \mathrm{C}, 3.5^{\circ} \mathrm{C}\right.$, and $\left.4.3^{\circ} \mathrm{C}\right)$ on the hydrate layer growth rate are explored.

\section{Experimental section}

\subsection{Materials}

In this study, materials utilized are cyclopentane (purity 98\%), $\mathrm{NaCl}$ (purity 99.5\%), $\mathrm{KCl}$ (purity 99.0\%), $\mathrm{Na}_{2} \mathrm{SO}_{4}$ (purity 99.5\%), and $\mathrm{MgCl}_{2}$ (purity 99.5\%). They were all furnished by SigmaAldrich. Distillated water (conductivity $<0.055 \mu \mathrm{S} . \mathrm{cm}^{1}$ ) was obtained from a decontamination system, Mili-Q®.

\subsection{Experimental apparatus}

Simplified diagram of experimental apparatus is presented in Figure 1. 
The main device is a horizontal jacketed reactor cell (1) with a volume of approximately $1.23 \mathrm{ml}$. This reactor has a height of $4 \mathrm{~mm}$, and a diameter of $19.8 \mathrm{~mm}$. The metal on the bottom and sides is inox. On the top is a sapphire window (8) in order to observe the system with both optical microscope and Raman microscope. A chiller (6), Ministat 240-Huber, with a temperature uncertainty of $0.02{ }^{\circ} \mathrm{C}$, is used to control the temperature of the inside solution, thanks to a cooling jacket (6). The coolant is a mixture of water and absolute ethanol (50\% v/v). A temperature probe (4) is utilized to monitor the solution temperature inside the reactor. Input (2) and output (3) lines are used to introduce, and also reject, the solutions. A microscope (10), connected to a camera (11), is employed to observe the crystallization of $\mathrm{CPH}$ through the transparent sapphire window (8) from the top. Because this reactor system usually works at low temperatures $\left(0-5^{\circ} \mathrm{C}\right)$, grams of silica gel (7) is used to absorb condensed water on the sapphire window surface in order to achieve quality images of crystallization. A transparent tube (9) is also used to prevent air from coming in, and to keep a low humidity level above the reactor. Digital data, including microscope images and temperature, are recorded by a computer (13) with a rate of 1 image every 5 minutes.

\subsection{Experimental protocol}

Before each experiment, chiller is set at a temperature according to the desired subcooling. Note that subcooling, $\Delta T_{s u b}$, is defined as the difference between the equilibrium temperature and the reactor temperature. The equilibrium temperatures of $\mathrm{CPH}$ in the presence of salts have been previously determined $[18,19]$. They are presented in Table 1.

At the beginning, in order to reduce the induction time of the crystallization, the saline solution is first used to form $\mathrm{CPH}$ in a bigger reactor (1L). Once $\mathrm{CPH}$ have been crystallized that way, hydrates are melted slowly with the heating rate of $0.1^{\circ} \mathrm{C} /$ hour, up to a temperature of $0.1^{\circ} \mathrm{C}$ above equilibrium. At this temperature, there should not be any crystals left the brine. Therefore, the initial salt concentration is regenerated in a solution close to thermodynamic equilibrium with liquid CP. Then, approximately $0.8 \mathrm{ml}$ of the solution is introduced into the reactor cell, followed by about $0.4 \mathrm{ml}$ of CP. It was observed that this "water preconditioning" reduces significantly the induction time, compared to the use of fresh water [53].

After stabilization, the microscope is set-up to observe the water/CP interface. Photos are taken every 5min. Hopefully, the first moments of the nucleation and growth are detected. 
After 3-4 days, when CPH has formed completely, videos are made from the previous pictures.

\section{Experimental Observations}

\subsection{Experimental layout}

7 mixtures at 3 different initial subcoolings have been considered. However, since the occurrence of crystallization is not easy to detect, only three selected runs will be discussed in details: in pure water at $2.5^{\circ} \mathrm{C}$ subcooling, in $5 \%$ equi-mass mixture of $\mathrm{NaCl}-\mathrm{KCl}-\mathrm{MgCl}_{2}$ at $3.5^{\circ} \mathrm{C}$ and $4.3^{\circ} \mathrm{C}$ initial subcoolings. Note that, in the case of salty mixtures, only the initial subcooling is controlled. Indeed, with the $\mathrm{CPH}$ crystallization, the average salinity of the aqueous phase changes, hence the subcooling. Since the objective is to investigate a batch process at constant temperature, this is normal. Finally, note that recorded videos are available online in "Supplementary information" (S1, S2, and S3). The speed of these videos is $50 \mathrm{~min} / \mathrm{s}$, corresponding to 10 frames per second, one picture every $5 \mathrm{~min}$.

\subsection{Interface shape}

Note that whatever the experience, the interface shape is similar (see Figure 2). Unexpectedly, the interface is not horizontal, even though $\mathrm{CP}$ is less dense than water. In the next pictures, $\mathrm{CP}$ phase is always on the left side, while the water phase is on the right side. The liquid-liquid interface clearly separates the two phases into two adjacent regions. Apparently, there is neither a droplet of CP into water, nor a droplet of water into CP. This is based on two observations: from microscopy, since the interface can be optically tracked by varying the focal length, but also from RAMAN spectroscopy. Indeed, the use of a RAMAN spectroscope (Horiba Xplora, 532nm laser) showed that, close to the $\mathrm{CP} /$ water interface, no water was detected between the substrates and the CP phase (points $A$ and $B$ on Figure 2), and likewise no CP was found between the substrates and brine (point $C$ ). Therefore, this infers that there is not a water film, respectively $\mathrm{CP}$ film, onto the substrate surfaces in the $\mathrm{CP}$ phase, respectively brine phase.

The physico-chemistry of components and interfaces (water/CP, walls/components) is the probable reason for such an atypical geometry. Of course, the configuration of the reactor cell (non-mixing, flat cylinder-shaped, very small height of $4 \mathrm{~mm}$ ), is the plausible reason why phase inversion cannot occur. Moreover, note that the process of injection is another determining 
factor. Indeed, the sequence of injection can change the final geometry. Hence, in order to obtain a clear vertical interface, water is always injected first.

\subsection{Experimental phenomenology of CPH growth}

Figure 3 illustrates the first interesting example (see also video S1). At the beginning appears a $\mathrm{CPH}$ nucleus in the $\mathrm{CP}$ phase (left). Apparently, some droplets of water are present in the $\mathrm{CP}$ phase, but without hydrates around them. There seem to be no CP droplets into the water phase (although this is possible out of the focus range). From stage 1 to stage 3, a triangle-shaped "single crystal" grows, and successive layers can be observed onto the surfaces of the crystal with time. At some moment, there is a sudden crystallization at the water-CP interface. Remember that the solution is supersaturated in $\mathrm{CPH}$, and it is not surprising to see such a rapid crystallization in the first steps. Then, step 4 corresponds to a growth of this interface, mostly toward CP phase. Note that the growth is not parallel to the interface, showing some preferential direction for the crystallization in the beginning. Somewhat later on, the interface shifts abruptly to the right. Later, step 5, there is a $\mathrm{CPH}$ growth on both sides, but still quicker toward the $\mathrm{CP}$ phase. At this moment, the growth seems to be parallel to the interface, at the same speed in all directions, although there are some exceptions. Moreover, there is a dramatic decrease of the crystal growth on the left side at the very end of the video, when the hydrate thickness is the most significant. In the end, $\mathrm{CPH}$ covers the whole observation plan.

A second key experiment (video S2) is illustrated in Figure 4. This is $\mathrm{CPH}$ formation from a 5\% equi-mass $\mathrm{NaCl}-\mathrm{KCl}-\mathrm{MgCl}_{2}$ aqueous phase under a $3.5^{\circ} \mathrm{C}$ initial subcooling. In this scenario, a $\mathrm{CPH}$ nucleus appears first in the water phase. Its shape is hexagonal; it grows rapidly in the very beginning, hence its size stabilizes (step 2-3). During steps 3, there is still a quick crystallization at the water/CP interface and the interface becomes rough. The $\mathrm{CPH}$ is then observed to grow volumetrically, but mostly at the expense of the CP liquid phase, between a CP-CPH "front" moving to the left and a CPH-bine interface that almost preserves the position of the initial $\mathrm{CP}$ brine contact. Suddenly (stage 4), the $\mathrm{CP}-\mathrm{CPH}$ and the $\mathrm{CPH}$-brine interfaces are shifted to the right, and their abrupt displacement is recorded thanks to the fixed reference given by the early formed hexagonal crystal. Later on, the crystallization proceeds mostly towards the CP phase (stage 5) and less so towards the water phase, layer by layer, at a varying speed, with occasional 
oscillation. Finally, note that the crystallization does not occur only in the microscope focus plan, showing blurry crystals above, or beneath, the crystallization front.

A last experiment, illustrated in figure 5, explores the same system as before, but at $4.3^{\circ} \mathrm{C}$ initial subcooling. Most of the previous observation can be made, and steps are quite similar. However, there is an exception to that. Between the quick interface crystallization and the interface shift + growth, there is a significant pause. This suggests that the interface shift is required by the volumetric changes linked to the ongoing reaction, but delayed by some mechanical resistance to displacement: a shear stress must be superrated for the displacement to occur; hence, when this stress is superated, the volume variation is acomodated and the interface shifts to the right. After this breakage, a growth toward the $\mathrm{CP}$ phase is observed. Again, the reaction front remains roughly parralel to the interface, although maybe not everywhere. Also, at this moment, the interface shift is not really noticeable. Nevertheless, at the final stage (6) there is a blurry phase growing and moving to the right, probably $\mathrm{CPH}$ formation above or below.

\subsection{CPH -forming front displacement velocity}

In order to investigate the kinetics of $\mathrm{CPH}$ formation, and the effect of salt on it, the hydrate layer growth rate of crystallization with and without salts, under different concentrations and initial subcoolings, has been measured. The CHP layer growth rate, $r$, is calculated as follows: $r=l / \Delta t$

where $l$ is the distance of the hydrate layer propagation, and $\Delta t$ the duration for this propagation. Note that, this rate $r$ represents either a time-averaged growth rate, by considering a significant $\Delta t$, or an instantaneous growth rate if $r(t)=d l / d t$. If the first possibility is easy to obtain, the calculation of the instantaneous hydrate layer growth rate $r(t)$ is more complicated since all the pictures need to be workable, which is rarely the case. In these calculations, the starting time is taken to be the beginning of the crystallization at the $\mathrm{CP} /$ water interface. Moreover, an average of ten different value of the $\mathrm{CPH}$ layer thickness $l$ at ten different positions of the CP-CPH interfaces in plain view have been used. Figure 6 illustrates such calculations in pure water at subcooling of $4.3^{\circ} \mathrm{C}$, and Table 2 provides numerical results of all calculations for different salt concentration and initial subcoolings, for three crystallization durations (60 min, 120min, and $180 \mathrm{~min})$. 
As expected, the $\mathrm{CPH}$ layer growth rate decreases over time. Note that our results agree well with the report on the thickness of $\mathrm{CPH}$ versus time according to Taylor et al. [54]. Their results pointed out that the $\mathrm{CPH}$ layer thickening rate is much higher at the first 0-40 min compared to that at the later periods. Moreover, CPH layer growth rate increases with increasing of the initial subcooling for all aqueous systems (pure water and electrolyte solutions), at the same crystallization time.

\section{Discussion on growth rate of the CPH layer}

Subcooling is related to the driving force of crystallization. Therefore, when it increases, the speed of hydrate formation increases. This phenomenon has been described in details elsewhere [47,48,52-57].

The decrease of the CPH layer growth rate when increasing the crystallization time can be explained as follows: In salty systems, the driving force for the crystallization changes with the increase in salinity due to the water consumption. Hence, the growth rate is expected to decrease with time. Also, a decrease of the growth speed is expected because of the increasing resistance to the mass transfers, especially water.

Furthermore, the growth rates in pure water are almost unsurprisingly higher than those in the presence of salts (except some particular cases: $\mathrm{NaCl}-\mathrm{MgCl}_{2} 3.5 \%$ mass and $\mathrm{Na}_{2} \mathrm{SO}_{4} 5 \%$ mass) at the same subcoolings and the same crystallization durations. Indeed, salts affect strongly both thermodynamic [19,44,57-59] and kinetic [57] of CPH formation. The exception of the $\mathrm{NaCl}-$ $\mathrm{MgCl}_{2} 3.5 \%$ mass and $\mathrm{Na}_{2} \mathrm{SO}_{4} 5 \%$ mass found no explanation.

In addition, the hydrate layer growth rates are different when considering different brine at the same subcoolings and same crystallization durations. This indicates that salts affect differently the kinetic of $\mathrm{CPH}$ formation. The reason of this variance is probably attributed to the different role of each salt in inhibiting the hydrate formation. Indeed, each salt has a different influence in weakening water hydrogen bonding and reducing $\mathrm{CP}$ solubility due to the difference in their solubility, salt ion charge density, and importantly water activity [60,61]. Thus, the formation of $\mathrm{CPH}$ is inhibited differently. Certainly, more experiments are required to discover clearly each salt effect on the kinetic of $\mathrm{CPH}$ formation. 
In comparison with literature, the lateral $\mathrm{CPH}$ crystal growth rate in pure water reported by Sakemoto et al [44] is approximately $0.0070-0.0090 \mathrm{~mm} / \mathrm{min}$ and $0.0420-0.0440 \mathrm{~mm} / \mathrm{min}$ under a subcooling of $2.4^{\circ} \mathrm{C}$ and $4.2^{\circ} \mathrm{C}$, respectively. While the first number is quite similar to our results $\left(0.0035 \mathrm{~mm} / \mathrm{min}\right.$ at $2.5^{\circ} \mathrm{C}$ subcooling at $\left.60 \mathrm{~min}\right)$, the second is significantly lower $(0.0055$ $\mathrm{mm} / \mathrm{min}$ under subcooling $4.3^{\circ} \mathrm{C}$ at $60 \mathrm{~min}$, see Table 2). Nevertheless, their system is different and presents a horizontal interface in a bigger volume.

However, in presence of $\mathrm{NaCl} 3.5 \%$ mass, Sakemoto et al [44] indicates a lateral hydrate crystal growth rate of $0.0020-0.0040 \mathrm{~mm} / \mathrm{min}$ at an initial subcooling of $2.4^{\circ} \mathrm{C}$, while our result calculation is $0.0024 \mathrm{~mm} / \mathrm{min}$ at $2.5^{\circ} \mathrm{C}$ initial subcooling at $60 \mathrm{~min}$. If the number are quite close (same order of magnitudes), this also reveals that the hydrate crystal growth rates reported by Sakemoto et al [44] are usually higher than our observations.

In addition, Taylor el al [54] reported the final $\mathrm{CPH}$ film thickness is approximately $15.2 \mu \mathrm{m}$ after $200 \mathrm{~min}$ at a subcooling of $3.8^{\circ} \mathrm{C}$ in pure water, indicating that the average thickening rate is about $0.076 \times 10^{-3} \mathrm{~mm} / \mathrm{min}$. Our observations (see table 2) present a rate of $0.0039 \mathrm{~mm} / \mathrm{min}$ at $60 \mathrm{~min}$ or $0.0036 \mathrm{~mm} / \mathrm{min}$ at $120 \mathrm{~min}$ at a subcooling of $3.5^{\circ} \mathrm{C}$, which is much higher than the value from Taylor et al [54].

These differences in the growth rate can be attributed to the different experimental systems and calculation. Indeed, Sakemoto et al. [44] defined this growth rate as an one-dimension growth rate of an individual hydrate crystal. Taylor el al [54] measured the final thickness of the interface in $200 \mathrm{~min}$, the average thickening rate is then calculated based on this measurement. In this work, the 2D polycrystalline hydrate layer growth rate in the nearly perpendicular direction to the water surface and CP surface are considered and not individual crystals (Figure 6). It was found that the hydrate growth in the perpendicular direction to the liquid-liquid interface is usually much more difficult than the lateral growth rate due to the slow mass transfer rate of water and CP across the hydrate layer [53]. Consequently, the growth rates from this present study and from Taylor el al [54] are significant lower than the individual crystal growth rate reported by Sakemoto et al [44].

\section{Discussion on CPH formation mechanism}

\subsection{First steps}


To begin with, Figure 7 is an attempt to capture what has been observed previously, except the apparent "hydrate breakage".

At the beginning, some nucleation sites near the liquid-liquid interface, either in CP phase or in water phase are witnessed. Sometimes, it can even be in both phases ( $1^{\text {st }}$ stage $)$. Indeed, the nucleation site is stochastic [62-65], and any impurity near the liquid-liquid interface can be an active nucleation center. Moreover, remember that the water used for the experiment is taken from a previous crystallization process. Therefore, it is a possibility that hydrate clusters remain in the water phase. Also, traces of $\mathrm{CP}$ (CP droplets) on the reactor surfaces, in the water phase, could be a source of formation of an individual hydrate crystal (hexagonal shaped on figures 4 and 7). Note that water droplets can also be present in the CP phase, leading to a nucleus (see figure 5). In order to simplify the mechanism, figure 7 only illustrates a nucleus in the water phase.

Later, the individual crystal grows by consuming the CP traces and water ( $2^{\text {nd }}$ stage). Quick nucleation and crystallization along the interface are then observed ( $3^{\text {rd }}$ stage). At this stage, the individual crystal also reaches its final size since all CP traces could have been consumed completely.

The hydrate layers grow mainly toward the $\mathrm{CP}$ phase by consuming initially water in the brine phase and also water dissolved in the CP phase near the liquid-liquid interface. Obviously, over time, the dissolved water becomes depleted, and water is hence required from the aqueous phase (discussed further). Accordingly, at the very beginning of the interface growth, there is only a growth toward CP phase, without interface shift. This comes right after.

\subsection{Interface shift and volume balance}

In the next step, a shift of the water-CPH interface into the water phase is observed ( $4^{\text {th }}$ stage). This is probably due to water consumption of crystallization. Remember that $\mathrm{CP}$ and water form hydrate structure II according to the following reaction:

$\mathrm{C}_{5} \mathrm{H}_{10}(\mathrm{CP})+17 . \mathrm{H}_{2} \mathrm{O}=\mathrm{C}_{5} \mathrm{H}_{10} .17 \mathrm{H}_{2} \mathrm{O}(\mathrm{CPH})$ 
Equation (2) indicates that one $\mathrm{CP}$ molecule combines with $17 \mathrm{H}_{2} \mathrm{O}$ molecules to form one $\mathrm{CPH}$ cell. Therefore, a large quantity of water is needed for the crystallization, leading a huge decrease in the volume of water phase.

Let us have a look at the volume balance of the process. Density of pure water at $4{ }^{\circ} \mathrm{C}$ is close to $1000 \mathrm{~kg} / \mathrm{m}^{3}$ (presence of salt decreases this density). Standard density of cyclopentane is 745 $\mathrm{kg} / \mathrm{m}^{3}$. At last, CPH density, considering full occupancy of large SII cavities, can be calculated to be $950-970 \mathrm{~kg} / \mathrm{m}^{3}[42,53,59,66,67]$, i.e. less than the liquid water phase, and more than liquid $\mathrm{CP}$. Based on these estimations, the volume balance is:

$\left\{\begin{array}{c}V_{m}(C P H)-\left[V_{m}(C P)+17 \cdot V_{m}\left(H_{2} O\right)\right]=\Delta V_{m} \\ 3.92 \cdot 10^{-1}-\left(9.41 \cdot 10^{-2}+17 \cdot 1 \cdot 8 \cdot 10^{-2}\right)=8 \cdot 33 \cdot 10^{-3} \mathrm{~L} / \mathrm{mol}\end{array}\right.$

Therefore, the volume diminution is about $8.3 \mathrm{~mL} / \mathrm{mol}$ of CP. Since about $0.8 \mathrm{~mL}$ of water is here introduced, a quick estimation indicates a volume change up to $22 \mu \mathrm{L}$, for full water consumption. As consequence, this volume reduction can induce a pressure difference between the two sides of the interface.

This pressure difference has not been investigated in details in this effort. An evaluation would be needed in the case of a modelling. Nevertheless, this is consistent with the study of Li et al. [32] reporting the sinking of the hydrate shell into a water droplet, in which the difference between inner and outside pressure is large enough due to the water permeation out the shell for crystallization. Finally, it is not surprising that an interface shift toward the water phase is observed since the ration $17: 1$ for the $\mathrm{CPH}$ crystallization corresponds to nearly $76 \%$ of the volume change occurring in the water phase.

\subsection{Hydrate growth and mass transfers}

Later (step 5 and after), CPH hydrates grow into both CP and water phases. However, the growth toward CP phase is obviously faster than toward the water phase. As discussed before, more water is needed to form $\mathrm{CPH}$. However, this growth on both sides demonstrates that water and CP molecules are migrating, probably inside de hydrate phase. 
Several possibilities can be considered. First, water phase and CP phase could always be in contact. This particular situation corresponds to a droplet of water in $\mathrm{CP}$, or the opposite, based on the kind of substrates. This is the situation of the lateral growth on a substrate. Martínez de Baños et al. $[53,68]$ especially observed and discussed this phenomena for water/CP system. They witnessed an initial fast crystallization at the water/CP interface, and then, the spread of an "halo" on a non-hydrophobic substrate, due to a water film between the substrate and CP. In this case, the limiting factor is the water mass transfer in this film. Since such water film was not observed in our system (see the discussion in "interface shape section"), this is not the mechanism expected in our apparatus, unless the water amount is so low that the Raman signal was not noticeable.

In the other case $\mathrm{CPH}$ form a wall between the two former species. The growth is therefore not substrate related. In order to observe the $\mathrm{CPH}$ growth, on both sides, former molecules need to cross this wall. Accordingly, this means that the hydrate phase is a porous medium, which is not surprising and documented in literature [30].

Let us have a closer look at $\mathrm{CPH}$ phase. $\mathrm{CPH}$ is believed to be more water-wettable than oilwettable [59,69-71]. This means that water phase can move more easily through the hydrate pore network than $\mathrm{CP}$, proving much more $\mathrm{H}_{2} \mathrm{O}$ for crystallization on the $\mathrm{CP}$ side than $\mathrm{CP}$ molecules for crystallization on the brine side, hence a faster growth toward CP phase. This observation agrees well with other studies. Davies et al [30] stated that the hydrate layer is initially porous and could be favorable to water transportation. In addition, their results illustrate that the growth of hydrate is controlled by the water migration within the hydrate layer. Also, Li et al [32] concluded from their experiments that hydrate layer thickening is controlled by the outward mass transport of water molecules across hydrate layer.

Another transport mechanism can be considered. Based on MD simulations, Liang et al [38] reported that the interstitial water molecules are mobile entities in the interior a hydrate. However, the rate difference of these two phenomena is not determined to our knowledge.

An illustration of the mass transfers across hydrate layer is illustrated in Figure 8. With the hydrate formation at the interface appears a wall. The interface is all covered by the polycrystalline hydrate and then it plays as a barrier to prevent water from contacting with guest molecules (CP) and vice versa, as presented in literature [2,15,34,51,54,72-77]. Moreover, the salinity then increases in the bulk of the brine phase because salts are excluded from hydrate 
crystallization $[29,78,79]$. Consequently, this shifts the thermodynamic equilibrium temperatures of $\mathrm{CPH}$ to lower values $[18,19,23]$. Thus, the crystallization rate is expected to decrease over time $[44,57]$.

Figure 8 illustrates that there are three likely mass movements through the hydrate layer: water advection toward $\mathrm{CP}$ phase, $\mathrm{CP}$ advection toward water phase, and salt diffusion toward water phase. Water and/or CP phase migration can only be driven by pressure gradients within the phase of interest. By definition, a capillary pressure is not a pressure gradient, but a pressure difference between two phases. Water or CP molecules (not phases) can migrate by transport and/or diffusion within any phase. The drive for advective transport is always a pressure gradient, and a chemical potential gradient for diffusive transport. Salt diffusion is driven by a gradient in chemical potential of salt in the bulk of the brine phase and in the filled hydrate pores. Certainly, because salts are excluded from crystallization, the salinity in the hydrate layer is higher than in bulk of the brine phase. Thus, salts tend to diffuse from hydrate pores to saline solution.

As aforementioned, there is a quick growth toward CP phase and a slow growth toward water phase. This difference in growth rate is related to the migration mechanism of $\mathrm{CP}$ and water, and also salts across hydrate layer. Indeed, during hydrate formation process, individual hydrate grains can join and generate some spaces, pores or channel (unknown geometry), in which water, $\mathrm{CP}$, and salts can move. According to the numerical study of Mori et al [25], water permeates through hydrate layer filling the capillaries. The driving force for this water permeation is the capillary pressure due to the hydrophilic characteristic of the hydrate surface. This agrees well with the observations using Raman spectrometer reported by Davies et al [30]. They stated that, in the polycrystalline hydrate layer, numerous visible pores or capillaries could be the mean for relatively high mobility water and also hydrate former migration across the hydrate film.

Our observations also indicate that the growth of the crystal interface remained somehow parallel to the $\mathrm{CPH}$ interface, without any obvious preferential direction, especially in the later steps. Therefore, it is suspected that the limiting step is the mass transfer. Pressure gradients are not negligible. When it is not the case, probably in the first steps, the crystal growth to be the limiting step can be expected. 
From a modelling viewpoint, mass transfer across a hydrate layer was numerically explored by Mori et al. $[25,26]$. However, these authors assumed a steady state where the hydrate layer forms at the hydrate-guest interface while it melts at the water-hydrate interface, thus maintaining a constant thickness. This is not strictly speaking a growth model, but the main concept to be retained from Mori et al 1997 [25], is that because gas hydrates are (presumably) hydrophilic, the pore space in the hydrate layer is (presumably) water-wet, hence a sustained water flux may be driven through the hydrate layer by the combined effects of capillary forces and the consumption of water at the hydrate-guest interface, where the hydrate actually grows.

In the presence of salts, there is also a mass transport of salt within the hydrate layer and the bulk of saline water. Obviously, hydrate formation excludes salt into saline solution and enhances the local salinity. Recently, the salt diffusion during hydrate crystallization was investigated by Meyer et al [29]. Salt diffusion is necessary to observe the hydrate growth in $\mathrm{CP} / \mathrm{CPH}$ interface, and therefore needs to be taken into account.

\section{Conclusion}

The formation of $\mathrm{CP}$ hydrate between brine and liquid $\mathrm{CP}$ was explored using a non-agitated small cell and a microscope allowing a top view of the processes and an evaluation of the lateral growth rate of the hydrate layer, under a variety of driving conditions and brine compositions.

The phenomenology of the hydrate formation involves the early formation of single crystals near the interface, as a likely consequence of the preparation of the system, where water is produced by melting previous CP hydrate. The volumetric Hydrate layer formation starts by a flash nucleation at the water-CP interface, then hydrate grows mostly, but not exclusively, at the expense of the $\mathrm{CP}$ phase, at a rate well recorded by the position of the $\mathrm{CP}-\mathrm{CPH}$ interface in time. Accordingly, the hydrate formation mechanism involves the advective transfer of the water phase through the porous hydrate layer which is, presumably, water-wet.

Not surprisingly, the measured growth rates increase linearly with increasing driving force (i.e. undercooling), and decreases with salt concentrations. This rate also decreases with time, in relation to the increased thickness of the hydrate layer and its increased resistance to the water transfer. 


\section{Supporting information.}

Video S1. CPH formation in pure water at a subcooling of $2.5^{\circ} \mathrm{C}$

Video S2. CPH formation in the presence of $\mathrm{NaCl}-\mathrm{KCl}-\mathrm{MgCl}_{2} 5 \%$ mass at a subcooling of $3.5^{\circ} \mathrm{C}$

Video S3. CPH formation in the presence of $\mathrm{NaCl}-\mathrm{KCl}-\mathrm{MgCl}_{2} 5 \%$ mass at a subcooling of $4.3^{\circ} \mathrm{C}$

\section{List of symbols used}

$l \quad[\mathrm{~mm}] \quad$ distance of the hydrate layer propagation

$r \quad\left[\mathrm{~mm} \cdot \mathrm{min}^{-1}\right] \quad$ cyclopentane hydrates layer growth rate

$t \quad$ [min] hydrate layer propagation time

$V_{m} \quad\left[{\mathrm{~L} . \mathrm{mol}^{-1}}^{-1} \quad\right.$ molar volume

\section{References}

[1] Sloan, E.D., Koh, C. A. Clathrate Hydrate of Natural Gases, 3rd ed.; CRC Press: Boca Raton, FL, 2008

[2] Sloan, E.D., Koh, C. A. and Sum, A. K. Natural Gas Hydrates in Flow Assurance, Gulf Professional Publishing, Elsevier Inc., 2011

[3] H. Mimachi, S. Takeya, A. Yoneyama, K. Hyodo, T. Takeda, Y. Gotoh, T. Murayama. Chem. Eng. Sci. 2014,118, 208-213. DOI:10.1016/j.ces.2014.07.050

[4] Z. Taheri, M.R. Shabani, K. Nazari, A. Mehdizaheh. J. Nat. Gas Sci. Eng. 2014, 21, 846849. DOI:10.1016/j.jngse.2014.09.026

[5] Sloan, E.D. Nature. 2003,426, 353-359. DOI:10.1038/nature02135

[6] Z.G. Sun, R. Wang, R. Ma, K. Guo, S. Fan. Energy Convers. Manag. 2003,44, 27332742. DOI:10.1016/S0196-8904(03)00048-7

[7] J. Lee, Y.K. Jin, Y. Seo. Chem. Eng. J. 2018, 338, 572-578.

DOI:10.1016/J.CEJ.2018.01.054

[8] H.P. Veluswamy, W.I. Chin, P. Linga. Int. J. Hydrogen Energy. 2014, 39, 16234-16243. DOI:10.1016/j.ijhydene.2014.01.054

[9] M. Sarshar, a H. Sharafi. Desalin. Water Treat. 2011, 28, 59-64. DOI:10.5004/dwt.2011.2201

[10] A. Burnol, I. Thinon, L. Ruffine, J.M. Herri. Int. J. Greenh. Gas Control. 2015, 35, 96- 
109. DOI:10.1016/j.ijggc.2015.01.018

[11] A. Galfré, M. Kwaterski, P. Braîntuas, A. Cameirao, J.M. Herri. J. Chem. Eng. Data. 2014, 59, 592-602. DOI:10.1021/je4002587

[12] S. Muromachi, H.D. Nagashima, J.M. Herri, R. Ohmura. J. Chem. Thermodyn. 2013, 64, 193-197. DOI:10.1016/j.jct.2013.05.020

[13] L.C. Ho, P. Babu, R. Kumar, P. Linga. Energy. 2013, 63, 252-259.

DOI:10.1016/j.energy.2013.10.031

[14] H. Liu, J. Wang, G. Chen, B. Liu, A. Dandekar, B. Wang, X. Zhang, C. Sun, Q. Ma. Int. J. Hydrogen Energy. 2014, 39, 7910-7918. DOI:10.1016/j.ijhydene.2014.03.094

[15] P. Babu, P. Linga, R. Kumar, P. Englezos. Energy. 2015, 85, 261-279. DOI:10.1016/j.energy.2015.03.103

[16] J. Douzet, M. Kwaterski, A. Lallemand, F. Chauvy, D. Flick, J.M. Herri. Int. J. Refrig. 2013, 36, 1616-1631. DOI:10.1016/j.ijrefrig.2013.04.015

[17] M. Darbouret, M. Cournil, J.M. Herri. Int. J. Refrig. 2005, 28, 663-671. DOI:10.1016/j.ijrefrig.2005.01.002

[18] S. Ho-Van, B. Bouillot, J. Douzet, S. Maghsoodloo Babakhani, J.-M. Herri. Ind. Eng. Chem. Res. 2018, 57 (43). DOI:10.1021/acs.iecr.8b02796

[19] S. Ho-Van, B. Bouillot, J. Douzet, S. Maghsoodloo, J.-M. Herri. Am. Inst. Chem. Eng. J. 2018, 64 (6). DOI:10.1002/aic.16067

[20] T. He, S.K. Nair, P. Babu, P. Linga, I.A. Karimi. Appl. Energy. 2018, 222, 13-24. DOI:10.1016/j.apenergy.2018.04.006

[21] S.H.B. Yang, P. Babu, S.F.S. Chua, P. Linga. Appl. Energy. 2016, 162, 1131-1140. DOI:10.1016/j.apenergy.2014.11.052

[22] P. Babu, A. Nambiar, T. He. ACS Sustain. Chem. Eng. 2018, 6 (7). DOI:10.1021/acssuschemeng.8b01616.

[23] S. Ho-Van, J. Douzet, D. Le-Quang, B. Bouillot, J.-M. Herri, in Proc. of the Int. Conf. on Integrated Petroleum Engineering (Eds: V.A.Tran et al.), Hanoi, Vietnam, November 2016, 150-157

[24] C. McAuliffe. J. Phys. Chem. 1966, 70, 1267-1275. DOI: 10.1021/j100876a049

[25] Y.H. Mori, T. Mochizuki. Chem. Eng. Sci. 1997, 52, 3613-3616. DOI:10.1016/S00092509(97)00169-3 
[26] Y.H. Mori, T. Mochizuki, in Proc. of 2nd Int. Conf. on Nat. Gas Hydrates (Eds: J.P.Monfort), Toulouse; France, 1996, 267-274

[27] Y.N. Lv, C.Y. Sun, B. Liu, G.J. Chen, J. Gong. AIChE J. 2017, 63, 1010-1023. DOI:10.1002/aic.15436

[28] X. Sun, B. Sun, Z. Wang, L. Chen, Y. Gao. Chem. Eng. Sci. 2017, 173, 168-178. DOI:10.1016/j.ces.2017.07.040

[29] D.W. Meyer, P.B. Flemings, D. Dicarlo, K. You, S.C. Phillips, T.J. Kneafsey. J. Geophys. Res. Solid Earth. 2018,123 (7). DOI:10.1029/2018JB015748

[30] S.R. Davies, E.D. Sloan, A.K. Sum, C.A. Koh. J. Phys. Chem. C. 2010, 114, 1173-1180. DOI:10.1021/jp909416y

[31] S.R. Davies, J.W. Lachance, E.D. Sloan, C.A. Koh. Ind. Eng. Chem. Res. 2010, 49, 12319-12326. DOI:10.1021/ie1017173

[32] S.L. Li, Y.F. Wang, C.Y. Sun, G.J. Chen, B. Liu, Z.Y. Li, Q.L. Ma. Chem. Eng. Sci. 2014, 135, 412-420. DOI:10.1016/j.ces.2015.01.057.

[33] H. Lo, M.T. Lee, S.T. Lin. J. Phys. Chem. C. 2017, 121, 8280-8289. DOI:10.1021/acs.jpcc.7b00853

[34] C.Y. Sun, B.Z. Peng, A. Dandekar, Q.L. Ma, G.J. Chen. Annu. Reports Prog. Chem. Sect. C. 2010, 106, 77-100. DOI:10.1039/b811053k

[35] M. Kishimoto, R. Ohmura. Energies. 2012, 5, 92-100. DOI:10.3390/en5010092

[36] C. Wang, X. Zhang, J. Li, L. Wang, L. Jioa. Adv. Mater. Res. 2013, 616-618, 902-906. DOI:10.4028/www.scientific.net/AMR.616-618.902

[37] J.D. Sundramoorthy, K.M. Sabil, B. Lal, P. Hammonds. Cryst. Growth Des. 2015, 15, 1233-1241. DOI:10.1021/cg501626h

[38] S. Liang, P.G. Kusalik. J. Am. Chem. Soc. 2011, 133, 1870-1876. DOI:10.1021/ja108434h

[39] S.L. Li, C.Y. Sun, G.J. Chen, Z.Y. Li, Q.L. Ma, L.Y. Yang, A.K. Sum. Chem. Eng. Sci. 2014, 116, 109-117. DOI:10.1016/j.ces.2014.04.009

[40] T. Mochizuki, Y.H. Mori. Chem. Eng. Sci. 2017, 171, 61-75. DOI:10.1016/j.ces.2017.05.015

[41] X. Sun, B. Sun, Z. Wang, L. Chen, Y. Gao. Int. J. Heat Mass Transf. 2018, 117, 940-950. DOI:10.1016/j.ijheatmasstransfer.2017.10.045 
[42] N. Hobeika, M.L. Martinez De Baños, P. Bouriat, D. Broseta, R. Brown. in: Gas Hydrates 1 (Eds: Daniel Broseta, Livio Ruffine, Arnaud Desmedt ) Wiley-ISTE. 2017,113-144. DOI:10.1002/9781119332688.ch3

[43] D. Daniel-David, F. Guerton, C. Dicharry, J.P. Torré, D. Broseta. Chem. Eng. Sci. 2015,132, 118-127. DOI:10.1016/j.ces.2015.04.015

[44] R. Sakemoto, H. Sakamoto, K. Shiraiwa, R. Ohmura, T. Uchida. Cryst. Growth Des. 2010, 10, 1296-1300. DOI:10.1021/cg901334z

[45] Y. Abe, X. Ma, T. Yanai, K. Yamane. AIChE J. 2016, 62, 4078-4089. DOI:10.1002/aic.15304

[46] X. Ma, Y. Abe, A. Kaneko, K. Yamane. Energy Procedia. 2014, 63, 5925-5932. DOI:10.1016/j.egypro.2014.11.628

[47] S. Li, C. Sun, B. Liu, Z. Li, G. Chen, A.K. Sum, Sci. Rep. 2014, 1-6. DOI:10.1038/srep04129

[48] S. Li, C. Sun, B. Liu, X. Feng, F. Li, L. Chen, G. Chen, AIChE J. 2013, 59 (6), 21452154. DOI:10.1002/aic

[49] M. Mitarai, M. Kishimoto, D. Suh, R. Ohmura, Cryst. Growth Des. 2015, 15, 812-821. DOI:10.1021/cg501613a

[50] K. Saito, M. Kishimoto, R. Tanaka, R. Ohmura, Cryst. Growth Des. 2011, 11, 295-301. doi:10.1021/cg101310z

[51] X. Sun, Z. Wang, B. Sun, L. Chen, J. Zhang. Chem. Eng. J. 2018, 331, 221-233. DOI:10.1016/j.cej.2017.08.105

[52] B.Z. Peng, A. Dandekar, C.Y. Sun, H. Luo, Q.L. Ma, W.X. Pang, G.J. Chen. J. Phys. Chem. B. 2007, 111, 12485-12493. DOI:10.1021/jp074606m

[53] M.L. Martinez de Baños, Mechanisms of formation and dissociation of cyclopentane hydrates, Ph.D. thesis, Université de Pau et des Pays de l'Adour, 2015

[54] C.J. Taylor, K.T. Miller, C.A. Koh, E.D. Sloan. Chem. Eng. Sci. 2007, 62, 6524-6533. DOI:10.1016/j.ces.2007.07.038

[55] E.M. Freer, M.S. Selim, E.D.S. Jr. Fluid Phase Equilib. 2001, 185, 65-75

[56] K. Saito, A.K. Sum, R. Ohmura. Society. 2010, 7, 7102-7103. DOI: 10.3390/En5010092

[57] M. Kishimoto, S. Iijima, R. Ohmura. Ind. Eng. Chem. Res. 2012, 51, 5224-5229. DOI:10.1021/ie202785z 
[58] G. Zylyftari, J.W. Lee, J.F. Morris. Chem. Eng. Sci. 2013, 95, 148-160. DOI:10.1016/j.ces.2013.02.056

[59] H. Delroisse, J.-P. Torré, C. Dicharry, Cryst. Growth Des. 2017, 17, 5098-5107. DOI:10.1021/acs.cgd.7b00241

[60] K.M. Sabil, V.R. Román, G.J. Witkamp, C.J. Peters. J. Chem. Thermodyn. 2010, 42, 400408. DOI:10.1016/j.jct.2009.09.012

[61] M. Cha, Y. Hu, A.K. Sum. Fluid Phase Equilib. 2016, 413, $2-9$. DOI:10.1016/j.fluid.2015.08.010

[62] P. Pirzadeh, P.G. Kusalik. J. Am. Chem. Soc. 2013, 135, 7278-7287. DOI:10.1021/ja400521e

[63] E. Dendy Sloan Jr. Nature. 2003, 426, 353-363

[64] L.C. Jacobson, W. Hujo, V. Molinero. J. Phys. Chem. B. 2010, 114, 13796-13807. DOI:10.1021/jp107269q

[65] C. Duchateau, P. Glénat, T.E. Pou, M. Hidalgo, C. Dicharry. Energy and Fuels. 2010, 24, 616-623. DOI:10.1021/ef900797e

[66] Sloan E., Jr. Marcel Dekker, Inc. Clathrate Hydrates of Natural Gases. Vol 14. Sencond ed.; 2000

[67] M. Nakajima, R. Ohinura, Y.H. Mori. Ind. Eng. Chem. Res. 2008, 47, 8933-8939. DOI:10.1021/ie800949k

[68] M.L.M. De Banos, N. Hobeika, P. Bouriat, D. Broseta, E. Enciso, F. Clément, R. Brown. Cryst. Growth Des. 2016, 16, 4360-4373. DOI:10.1021/acs.cgd.6b00471

[69] P.U. Karanjkar, A. Ahuja, G. Zylyftari, J.W. Lee, J. F. Morris. Rheol. Acta. 2016, 55, 235-243. DOI:10.1007/s00397-016-0911-1

[70] G. Aspenes, L.E. Dieker, Z.M. Aman, S. Høiland, A.K. Sum, C.A. Koh, E.D. Sloan. J. Colloid Interface Sci. 2010, 343, 529-536. DOI:10.1016/j.jcis.2009.11.071

[71] E.P. Brown, S. Hu, J. Wells, X. Wang, C.A. Koh. Energy and Fuels. 2018, 32, 66196626. DOI:10.1021/acs.energyfuels. 8 b00803

[72] M. Sugaya, Y.H. Mori. Chem. Eng. Sci. 1996, 51, 3505-3517. DOI:10.1016/00092509(95)00404-1

[73] T.Y. Makogon, R. Larsen, C.A. Knight, E.D. Sloan. J. Cryst. Growth. 1997, 179, 258-262

[74] X. Sen Li, C.G. Xu, Z.Y. Chen, H.J. Wu. Energy. 2011, 36, 1394-1403. 
DOI:10.1016/j.energy.2011.01.034

[75] P.U. Karanjkar, J.W. Lee, J.F. Morris. Chem. Eng. Sci. 2012, 68, 481-491. DOI:10.1016/j.ces.2011.10.014

[76] P. Linga, R. Kumar, P. Englezos. Chem. Eng. Sci. 2007, 62, 4268-4276. DOI:10.1016/j.ces.2007.04.033

[77] H. Dong, Z. Fan, B. Wang, S. Xue, J. Zhao, Y. Song. Energy Procedia. 2017, 105, 47064712. DOI:10.1016/j.egypro.2017.03.1020

[78] X. Liu, P.B. Flemings. Earth Planet. Sci. Lett. 2006, 241, 211-226.

DOI:10.1016/j.eps1.2005.10.026

[79] R. Hesse, W.E. Earth Planet. Sci. Lett. 1981, 55, 453-462. DOI:10.1016/0012$821 X(81) 90172-2$ 
Table 1. CPH equilibrium temperature in different solutions [18,19]

\begin{tabular}{ccc}
\hline Solutions & Salinity $^{\mathrm{a}, \mathrm{b}, \mathrm{c}}, \%$ mass & $\mathrm{CPH}$ equilibrium temperature, $\pm 0.1^{\circ} \mathrm{C}$ \\
\hline Pure water & - & 7.1 \\
$\mathrm{NaCl}$ & 3.5 & 5.5 \\
$\mathrm{NaCl}-\mathrm{MgCl}_{2}$ & 3.5 & 5.1 \\
$\mathrm{NaCl}-\mathrm{KCl}-\mathrm{MgCl}_{2}$ & 3.5 & 5.2 \\
$\mathrm{NaCl}-\mathrm{KCl}-\mathrm{MgCl}_{2}$ & 5.0 & 4.6 \\
$\mathrm{Na}_{2} \mathrm{SO}_{4}$ & 3.5 & 6.0 \\
$\mathrm{Na}_{2} \mathrm{SO}_{4}$ & 5.0 & 5.6
\end{tabular}

${ }^{a}$ Uncertainty due to weighing: $\pm 0.002 \%$ mass. ${ }^{b}$ Uncertainty due to drying oven: $\pm 0.2 \%$ mass. ${ }^{\text {cRelative }}$ uncertainty due to ion chromatography: $1.5 \%$ (see the Supporting Information from Ho-Van et al.[19] for all uncertainty estimations). 
Table 2. Measured CPH layer growth rate in different subcoolings and brine solutions with time.

\begin{tabular}{|c|c|c|c|c|c|c|c|c|c|}
\hline \multirow{3}{*}{ Aqueous solution } & \multicolumn{9}{|c|}{ Propagation rate, $\mathrm{mm} \cdot \mathrm{min}^{-1}$} \\
\hline & \multicolumn{3}{|c|}{$\Delta \mathrm{T}_{\mathrm{sub}}=2.5^{\circ} \mathrm{C}$} & \multicolumn{3}{|c|}{$\Delta \mathrm{T}_{\text {sub }}=3.5^{\circ} \mathrm{C}$} & \multicolumn{3}{|c|}{$\Delta \mathrm{T}_{\text {sub }}=4.3^{\circ} \mathrm{C}$} \\
\hline & $60 \mathrm{~min}$ & $120 \mathrm{~min}$ & 180min & $60 \mathrm{~min}$ & $120 \mathrm{~min}$ & $180 \mathrm{~min}$ & $60 \mathrm{~min}$ & $120 \mathrm{~min}$ & $180 \mathrm{~min}$ \\
\hline \multirow[t]{2}{*}{ Pure water } & 0.0035 & 0.0033 & 0.0025 & 0.0039 & 0.0036 & NA & 0.0055 & 0.0049 & 0.0037 \\
\hline & \pm 0.0004 & \pm 0.0002 & \pm 0.0002 & \pm 0.0002 & \pm 0.0004 & & \pm 0.0005 & \pm 0.0006 & \pm 0.0003 \\
\hline \multirow[t]{2}{*}{$\mathrm{NaCl} 3.5 \%$ mass } & 0.0024 & 0.0018 & 0.0016 & 0.0040 & 0.0027 & 0.0020 & 0.0046 & NA & NA \\
\hline & \pm 0.0004 & \pm 0.0003 & \pm 0.0003 & \pm 0.0005 & \pm 0.0002 & \pm 0.0002 & \pm 0.0005 & & \\
\hline $\mathrm{NaCl}-\mathrm{MgCl}_{2} 3.5 \%$ & 0.0022 & 0.0017 & 0.0014 & 0.0045 & 0.0033 & NA & 0.0063 & 0.0041 & 0.0041 \\
\hline mass & \pm 0.0003 & \pm 0.0005 & \pm 0.0002 & \pm 0.0005 & \pm 0.0002 & & \pm 0.0006 & \pm 0.0006 & \pm 0.0008 \\
\hline $\mathrm{NaCl}-\mathrm{KCl}-\mathrm{MgCl}_{2}$ & 0.0013 & 0.0009 & NA & 0.0039 & 0.0031 & 0.0023 & 0.0054 & NA & NA \\
\hline $3.5 \%$ mass & \pm 0.0002 & \pm 0.0002 & & \pm 0.0008 & \pm 0.0004 & \pm 0.0004 & \pm 0.0005 & & \\
\hline $\mathrm{NaCl}-\mathrm{KCl}-\mathrm{MgCl}_{2}$ & 0.0011 & 0.0008 & 0.0006 & 0.0016 & 0.0011 & 0.0008 & 0.0020 & 0.0014 & 0.0011 \\
\hline $5 \%$ mass & \pm 0.0002 & \pm 0.0001 & \pm 0.0001 & \pm 0.0003 & \pm 0.0004 & \pm 0.0001 & \pm 0.0001 & \pm 0.0002 & \pm 0.0001 \\
\hline $\mathrm{Na}_{2} \mathrm{SO}_{4} 3.5 \%$ & 0.0009 & 0.0006 & 0.0006 & 0.0018 & 0.0012 & 0.0010 & 0.0020 & 0.0013 & 0.0010 \\
\hline mass & \pm 0.0001 & \pm 0.0001 & \pm 0.0001 & \pm 0.0003 & \pm 0.0002 & \pm 0.0002 & \pm 0.0002 & \pm 0.0003 & \pm 0.0001 \\
\hline \multirow[t]{2}{*}{$\mathrm{Na}_{2} \mathrm{SO}_{4} 5 \%$ mass } & 0.0009 & 0.0007 & 0.0005 & 0.0040 & 0.0038 & NA & 0.0089 & NA & NA \\
\hline & \pm 0.0001 & \pm 0.0001 & \pm 0.0001 & \pm 0.0001 & \pm 0.0001 & & \pm 0.0002 & & \\
\hline
\end{tabular}

NA: Not Acknowledge 


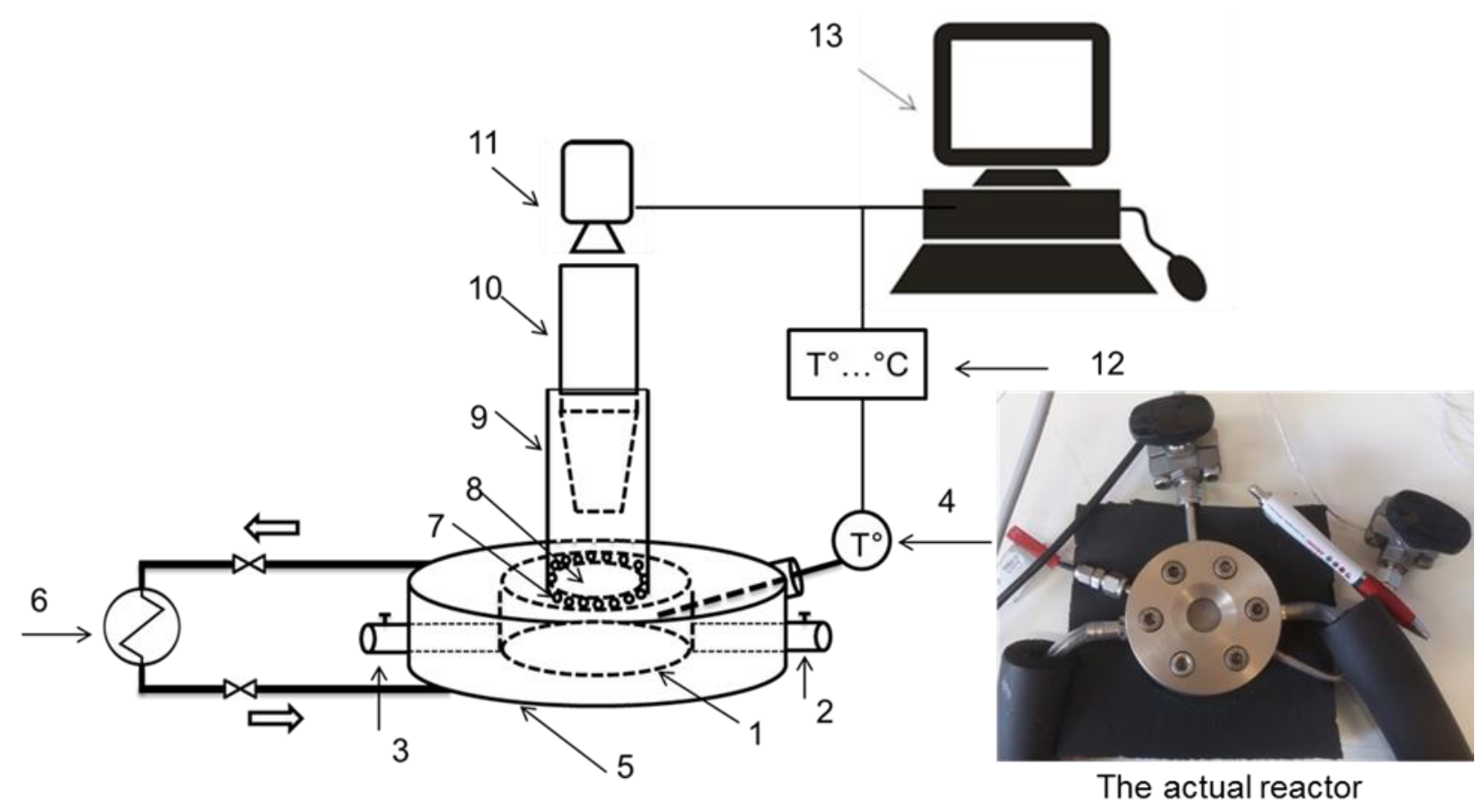

Figure 1. Schematic illustration of the experimental set-up

Reactor cell; (2) input line; (3) output line; (4) Temperature probe; (5) Cooling jacket; (6)

Chiller; (7) Silica gel; (8) Sapphire window; (9) Transparent tube; (10) Objective lens; (11) Camera; (12) Temperature transmitter; (13) Computer 


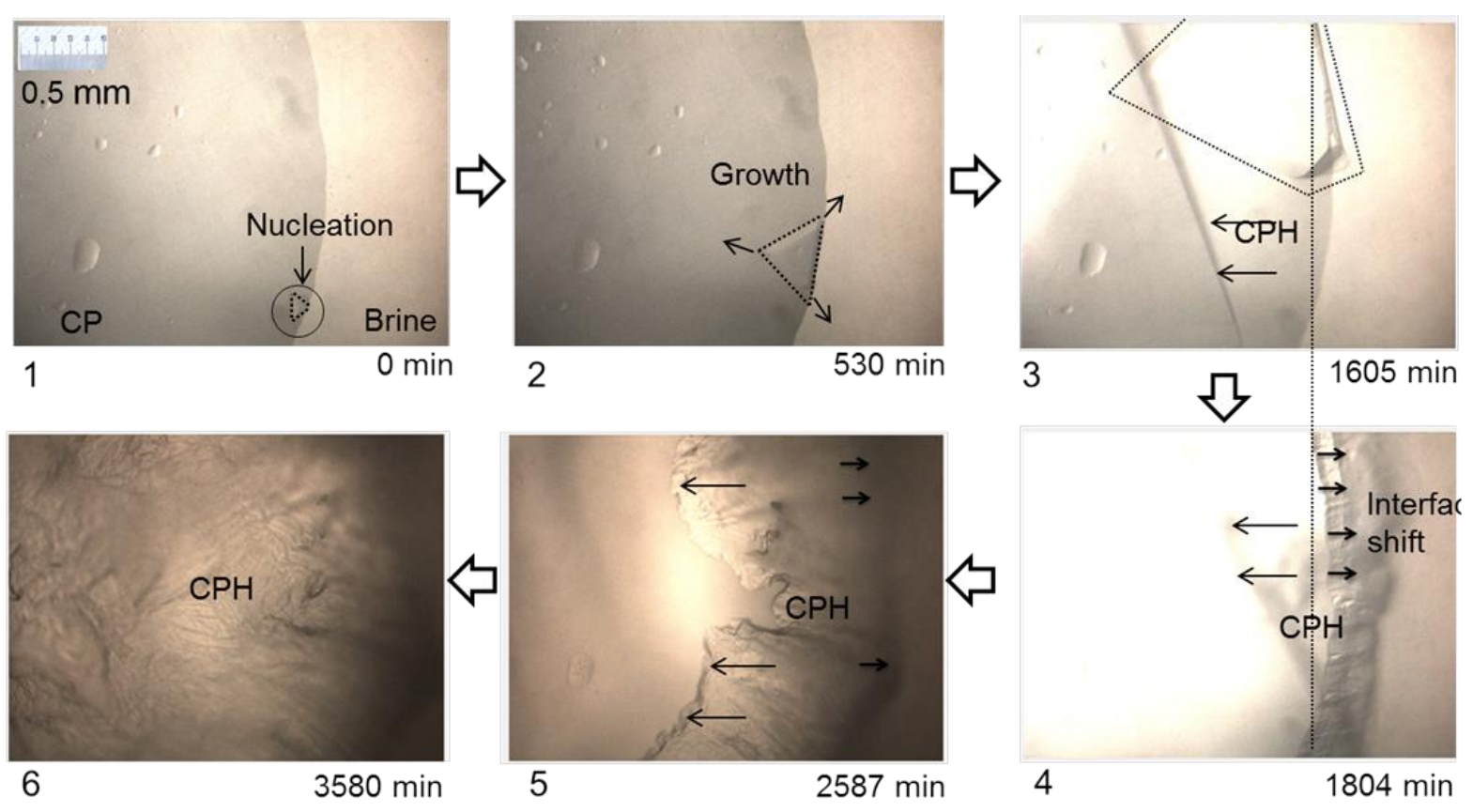

Figure 2. Schematic illustration of the hydrate layer in the reactor-cell 

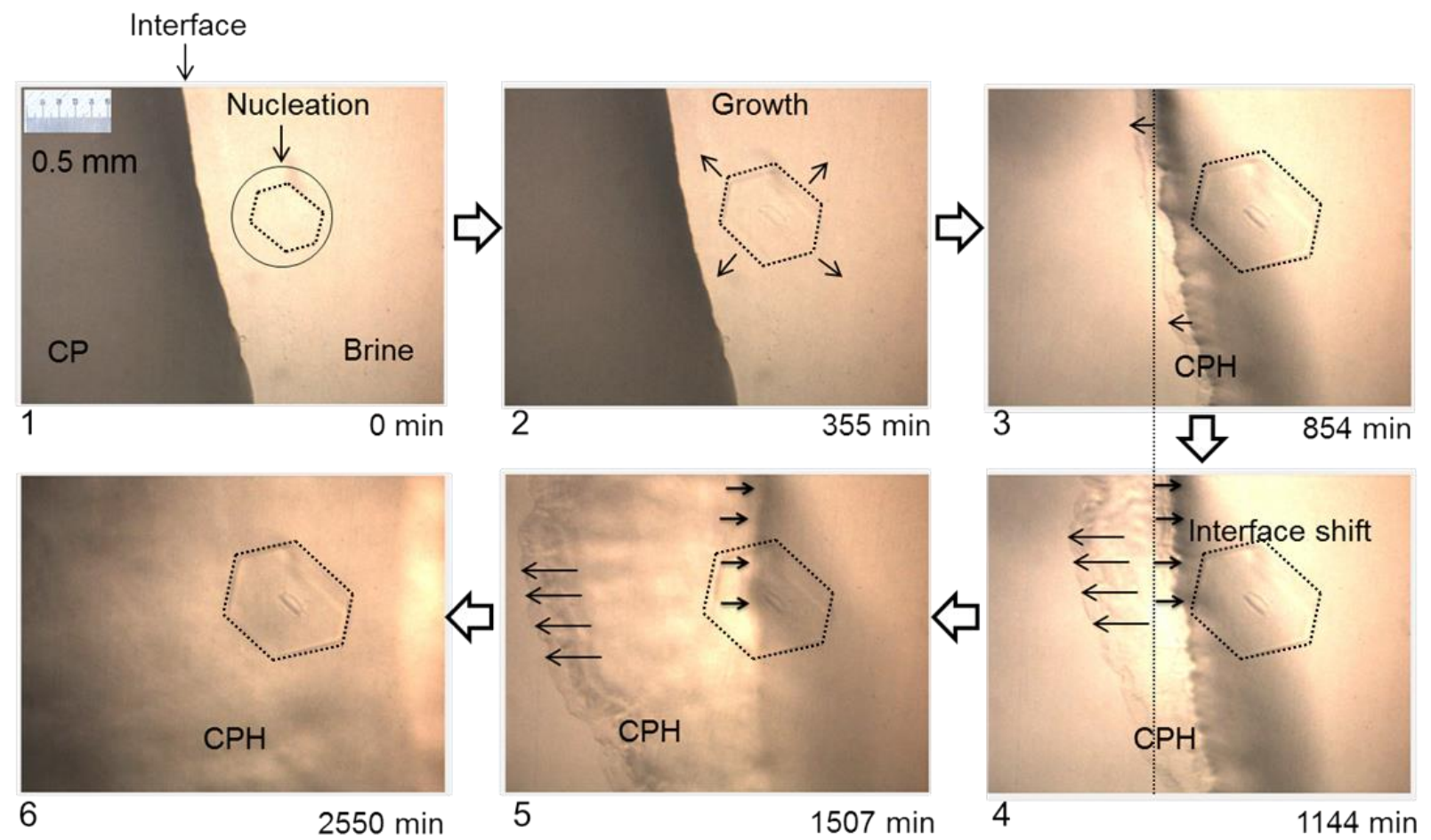

Figure 3. CPH crystallization mechanism in the presence of pure water at an initial subcooling of $2.5^{\circ} \mathrm{C}$. Arrows indicate moving crystal boundaries (single crystal growth) or interface boundary 


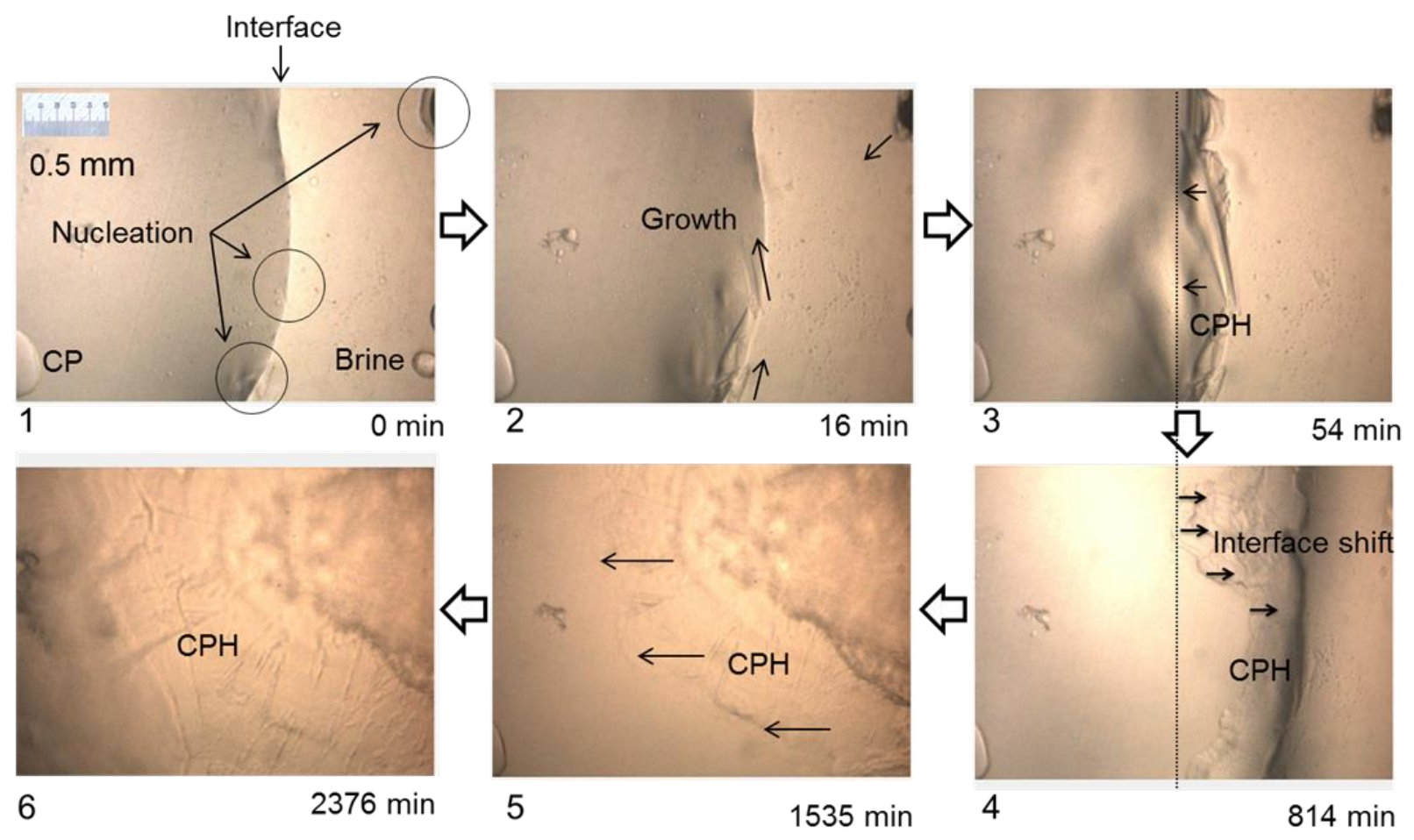

Figure 4. $\mathrm{CPH}$ crystallization mechanism in the presence of $\mathrm{NaCl}-\mathrm{KCl}-\mathrm{MgCl} 25 \%$ at an initial subcooling of $3.5^{\circ} \mathrm{C}$. 


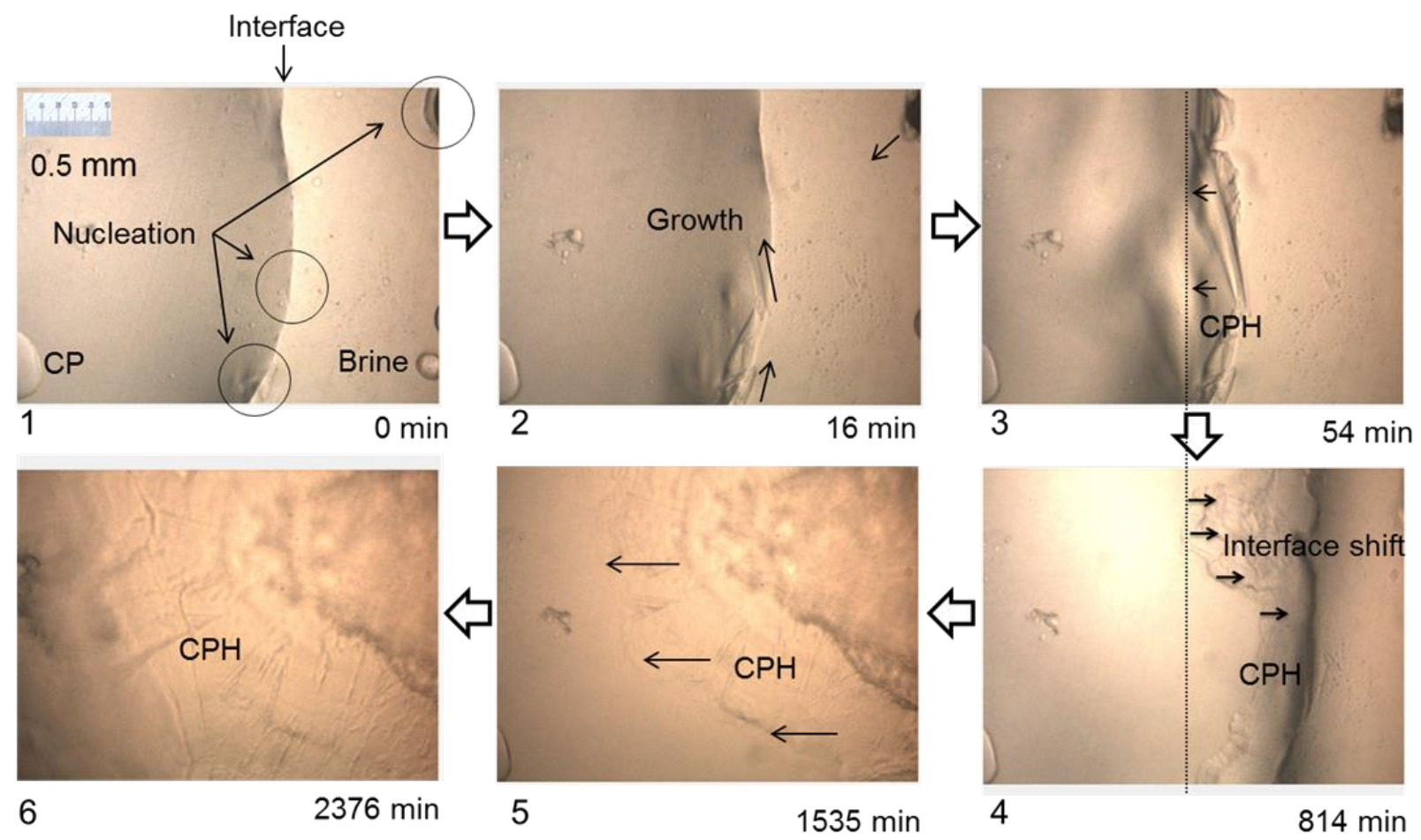

Figure 5. $\mathrm{CPH}$ crystallization mechanism in the presence of $\mathrm{NaCl}-\mathrm{KCl}-\mathrm{MgCl}_{2} 5 \%$ at an initial subcooling of $4.3^{\circ} \mathrm{C}$ 


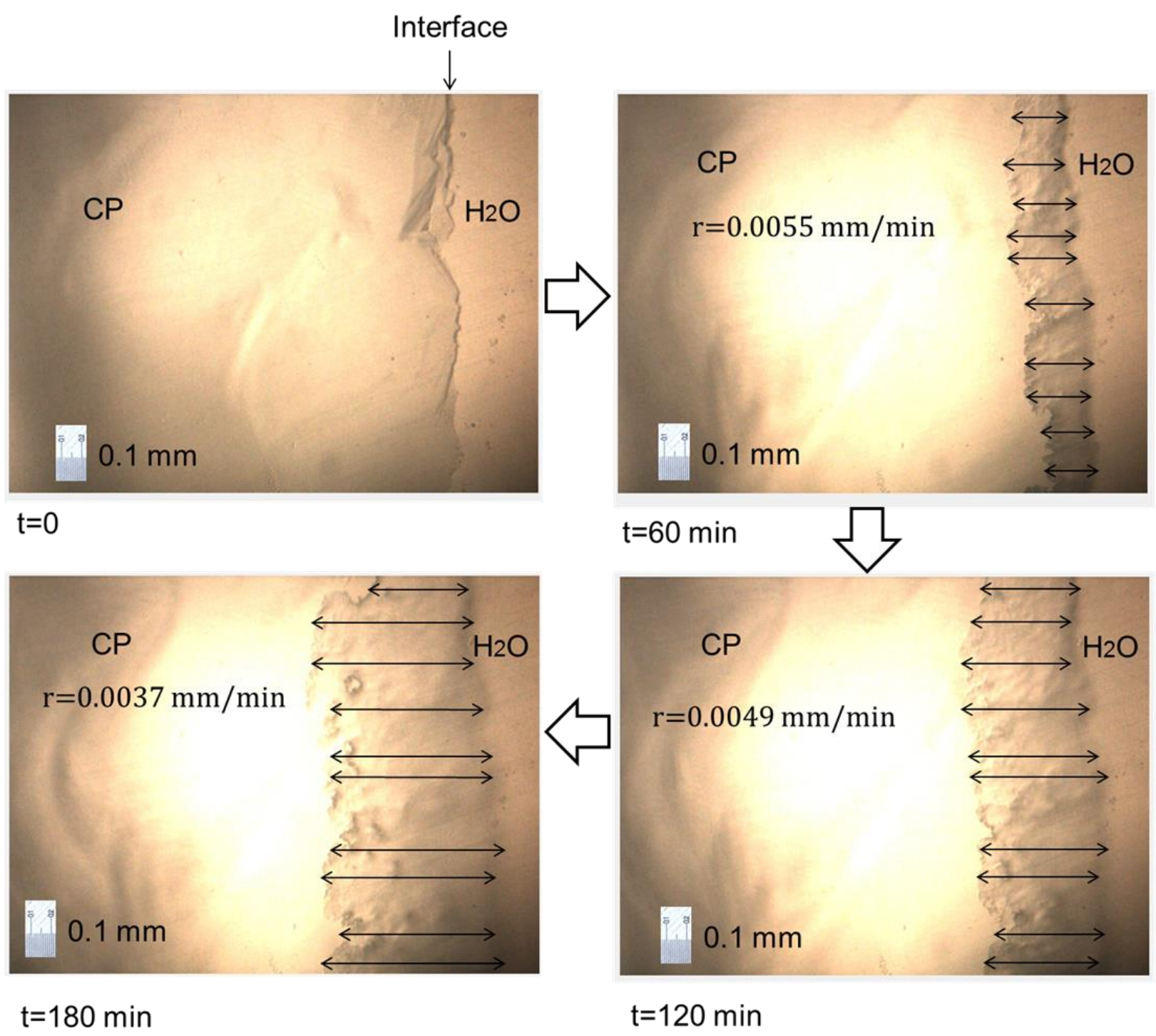

Figure 6. $\mathrm{CPH}$ layer growth rate in pure water at $4.3^{\circ} \mathrm{C}$ subcooling after $60 \mathrm{~min}, 120 \mathrm{~min}$, and $180 \mathrm{~min}$ 


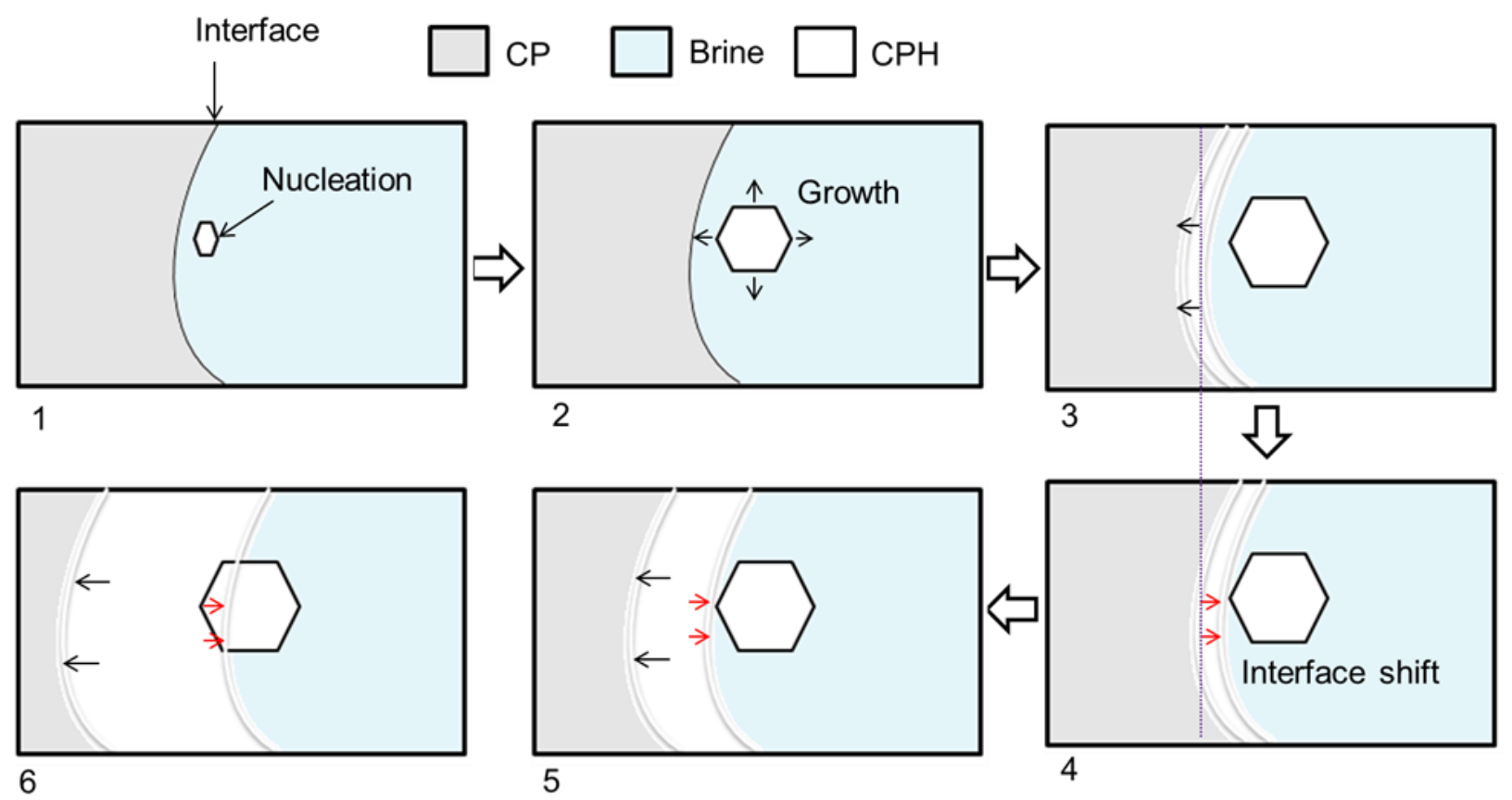

Figure 7. Simplified schematic of the $\mathrm{CPH}$ crystallization mechanism of near the interface in the reactor cell 


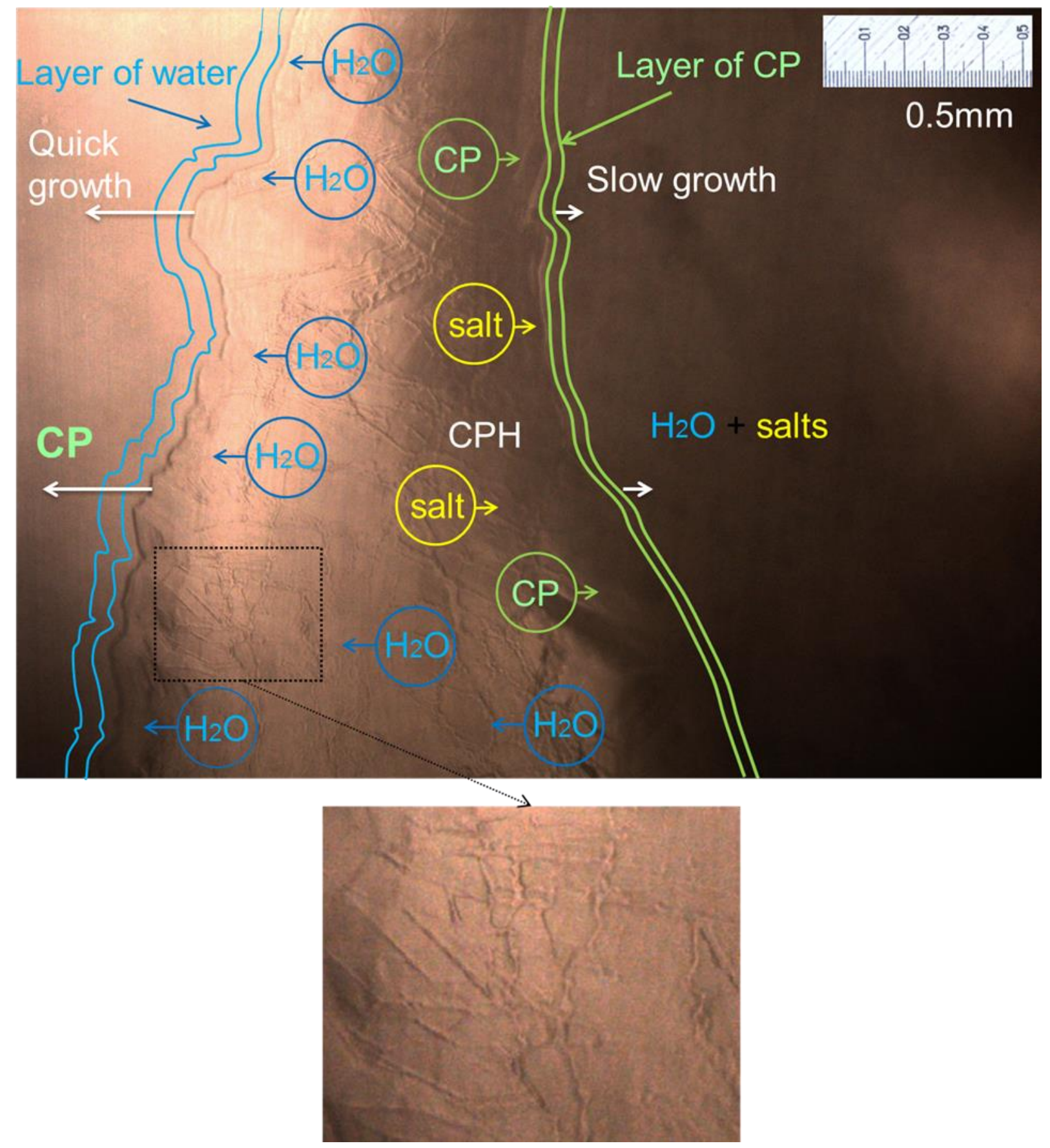

Figure 8. Mass transfer at the $\mathrm{CPH}$ interface during crystallization (illustration based on the photo taken from the experiment with $\mathrm{NaCl}-\mathrm{KCl}-\mathrm{MgCl}_{2} 5 \%$ mass at subcooling $2.5^{\circ} \mathrm{C}$ ) 


\section{Figure Legend}

\begin{tabular}{|c|c|}
\hline Figure 1 & $\begin{array}{l}\text { Schematic illustration of the experimental set-up } \\
\text { (1) Reactor cell; (2) input line; (3) output line; (4) Temperature probe; (5) Cooling } \\
\text { jacket; (6) Chiller; (7) Silica gel; (8) Sapphire window; (9) Transparent tube; (10) } \\
\text { Objective lens; (11) Camera; (12) Temperature transmitter; (13) Computer. }\end{array}$ \\
\hline Figure 2 & Schematic illustration of the hydrate layer in the reactor-cell \\
\hline Figure 3 & $\begin{array}{l}\mathrm{CPH} \text { crystallization mechanism in the presence of pure water at an initial subcooling of } \\
2.5^{\circ} \mathrm{C} \text {. Arrows indicate moving crystal boundaries (single crystal growth) or interface } \\
\text { boundary }\end{array}$ \\
\hline Figure 4 & $\begin{array}{l}\mathrm{CPH} \text { crystallization mechanism in the presence of } \mathrm{NaCl}-\mathrm{KCl}-\mathrm{MgCl}_{2} 5 \% \text { at an initial } \\
\text { subcooling of } 3.5^{\circ} \mathrm{C}\end{array}$ \\
\hline Figure 5 & $\begin{array}{l}\mathrm{CPH} \text { crystallization mechanism in the presence of } \mathrm{NaCl}-\mathrm{KCl}-\mathrm{MgCl}_{2} 5 \% \text { at an initial } \\
\text { subcooling of } 4.3^{\circ} \mathrm{C}\end{array}$ \\
\hline Figure 6 & $\mathrm{CPH}$ layer growth rate in pure water at $4.3^{\circ} \mathrm{C}$ subcooling after $60 \mathrm{~min}, 120 \mathrm{~min}$, and $180 \mathrm{~min}$ \\
\hline Figure 7 & $\begin{array}{l}\text { Simplified schematic of the } \mathrm{CPH} \text { crystallization mechanism of near the interface in the } \\
\text { reactor cell }\end{array}$ \\
\hline Figure 8 & $\begin{array}{l}\text { Mass transfer at the } \mathrm{CPH} \text { interface during crystallization (illustration based on the photo } \\
\text { taken from the experiment with } \mathrm{NaCl}-\mathrm{KCl}-\mathrm{MgCl}_{2} 5 \% \text { mass at subcooling } 2.5^{\circ} \mathrm{C} \text { ) }\end{array}$ \\
\hline
\end{tabular}




\section{Table Legend}

\begin{tabular}{|l|c|}
\hline Table 1 & CPH equilibrium temperature in different solutions $[18,19]$ \\
\hline Table 2 & Measured CPH layer growth rate in different subcoolings and brine solutions with time \\
\hline
\end{tabular}




\section{Table of Contents: Graphical Abstract}

Cyclopentane hydrates are considered to be a candidate for hydrate-based desalination. Thus, mechanism of cyclopentane hydrate crystallization in pure water and in brine is crucial. In this contribution, varied salts at different concentrations and under three driving forces (subcooling) were considered to discover the phenomenology of hydrate formation, utilizing an optical microscope. An effort of measuring the hydrate growth speeds was also conducted.

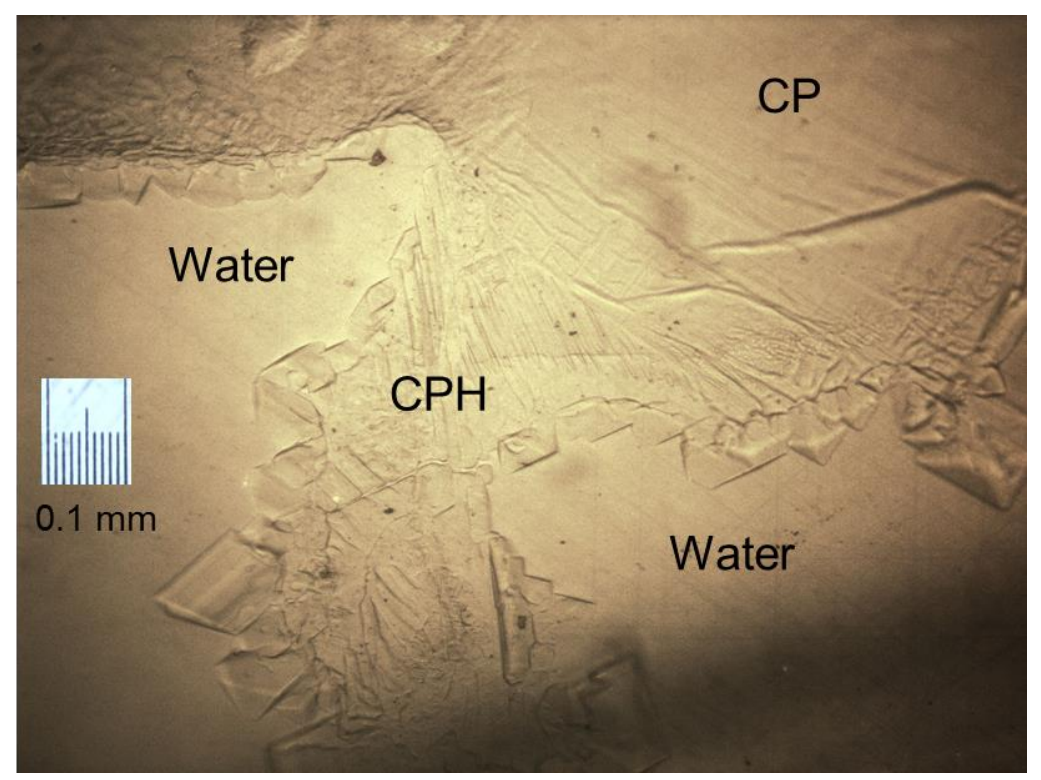

Cyclopentane hydrates crystallization near the liquid-liquid interface between water and cyclopentane 